\title{
What do therapists and clients talk about when they cannot explain behaviours? How Carl Jung avoided analysing a client's environments by inventing theories
}

\section{O que os terapeutas e os clientes falam quando eles não conseguem explicar os comportamentos? Como Carl Jung inventou teorias para evitar analisar o ambientes de uma cliente}

\author{
¿De que hablan terapeutas y clientes cuando no pueden explicar los \\ comportamientos? Como Carl Jung inventó teorías para evitar analizar los \\ ambientes de una cliente
}

\section{Bernard Guerin ${ }^{1}$}

\begin{abstract}
Resumo: Em um primeiro momento, esse artigo vai abordar três pontos: 1) as variáveis que modelam o que chamamos de questões de saúde mental estão "escondidas"; 2) nas terapias atuais é dominante o uso da linguagem como forma de modificar o comportamento, mas esse modelo já atingiu o seu limite; 3) quando somos solicitados a explicar nossos próprios comportamentos e não somos capazes de fazê-lo usamos outras estratégias discursivas comuns na tentativa de conseguir responder essa questão: mentalismo, abstrações, responder com outras questões, personificações, o uso emotivo da linguagem e distrações. Então, esses três pontos são usados para mostrar como a história da terapia tem levado terapeutas a usar essas estratégias discursivas. Desde o tempo de Freud e Jung, as terapias se desenvolveram e a sociedade ocidental mudou de tal maneira que as forças que modelam o comportamento das pessoas deixaram de estar na família e passaram a estar no contato onipresente com estranhos, burocracias e "outros generalizados". Como as pessoas não poderiam facilmente observar ou falar sobre essas novas contingências sociais amorfas, terapeutas e clientes recorriam às estratégias discursivas do senso comum. Isso é ilustrado por meio da recontextualização de um dos estudos de caso do Jung para mostrar que as questões das clientes estavam nas situações externas (patriarcado) e não "dentro da sua cabeça" ou em um "arquétipo coletivo pertencente ao inconsciente coletivo", que é uma das metáforas que Jung inventou para encobrir a sua inabilidade de articular com novas formas sociais de modelação pelas quais os seus clientes estavam passando. Adicionando nas novas e excitantes formas de terapias comportamentais mais analises dessas contingencias sociais escondidas, poderá se chegar em um ponto além do uso da linguagem para ajudar os clientes a mudarem os seus mundos. Para analisar e mudar as influências sociais escondidas do patriarcado, da economia, da política e da burocracia, os terapeutas devem aprender a reconhecer e analisar essas novas forças na vida das pessoas e então trabalhar com eles fora do setting terapêutico, ou dentro usando a linguagem, para mudar os seus mundos, como já acontece em algumas novas formas da terapia comportamental e da terapia feminista.
\end{abstract}

Palavras-chave: terapia, contingências sociais, saúde mental, linguagem terapêutica, Jung, patriarcado, ativismo como terapia. 


\begin{abstract}
This paper first argues for three points: (1) that the shapers of what we call mental health issues are 'hidden'; (2) that language use is currently the dominant therapy to change people's behaviours but this has reached its limits; and (3) that when we are asked to explain our own behaviours but are unable, we use other common strategies of discourse to cover this gap: mentalisms, abstractions, replying with questions, personifications, the use of 'emotive' language, and distractions. These three points are then used to recreate how the history of therapy has led therapists to use these strategies of discourse. From the time of Freud and Jung, as therapy itself was developed, western society changed so that the forces now shaping people's behaviour moved from family to ubiquitous contact with strangers, bureaucracies, and 'generalized others'. Because people could not easily observe or speak about these new amorphous societal shapers, therapists and clients resorted to those everyday discursive strategies. This is illustrated through re-contextualizing one of Jung's case studies to show that the client's 'issues' were in her external situations (patriarchy) and not 'in her head' or an 'archetype in the 'collective unconscious', which was one of the abstract metaphors Jung invented to cover his inability to also articulate the new forms of societal shaping of his client. Adding more analyses of hidden societal and social contingencies into the exciting new behaviour therapies will produce new ways of going beyond the sole use of language to help clients change their worlds. To analyse and change the hidden societal influences from patriarchy, economics, politics, and bureaucracy, therapists must either learn to recognize and analyse these new forces on a person's life and then work with them outside the therapy setting, or inside using language, to change their worlds, as already happens in some of the new behaviour therapies and feminist ther apies.
\end{abstract}

Keywords: therapy, societal contingencies, mental health, language in therapy, Jung, patriarchy, activism as therapy.

Resumen: En un primer momento, este artículo va a abordar tres puntos: (1) Las variables que moldean lo que llamamos problemas de salud mental están 'ocultas'; (2) en las terapias de la actualidad es dominante el uso del lenguaje como manera de cambiar los comportamientos, pero este modelo ha alcanzado sus límites; (3) cuando se nos pide que expliquemos nuestros comportamientos, pero no lo podemos, utilizamos otras estrategias comunes de discurso para cubrir esta brecha: mentalismo, abstracciones, contestaciones con nuevas preguntas, personificaciones, el uso emocional del idioma y distracciones. Estos tres puntos se utilizan entonces para recrear cómo la historia de la terapia tiene llevado terapeutas a utilizar estas estrategias de discurso. Desde el tiempo de Freud y Jung, cuando las terapias se desarrollaron, la sociedad occidental cambió de tal manera que las fuerzas que ahora moldean el comportamiento de la gente han cambiado desde la familia hasta un contacto omnipresente con estraños, burocracias, y 'otros generalizados'. Como las personas no pueden observar o hablar facilmente sobre estos nuevos moldeadores sociales amorfos, los terapeutas y los clientes recurren a esas estrategias discursivas cotidianas. Esto se ilustra a través de la re-contextualización de uno de los estudios de caso de Jung para mostrar que los "problemas" de la cliente estaban en sus situaciones externas (patriarcado) y no "en su cabeza" o en un "arquetipo del 'inconsciente colectivo', que fue una de las metáforas abstractas que Jung inventó para cubrir su incapacidad para también articular las nuevas formas de conformación social de su cliente. Agregar a las excitantes nuevas terapias del comportamiento más análisis de contingencias ocultas societales y sociales producirá nuevas formas de ir más allá del uso exclusivo del lenguaje para ayudar a los clientes a cambiar sus mundos. Para analizar y cambiar las influencias sociales ocultas del patriarcado, la economía, la política y la burocracia, los terapeutas deben aprender a reconocer y analizar estas nuevas fuerzas en la vida de una persona y luego trabajar con ellas fuera del entorno de la terapia, o utilizar el lenguaje en el interior de la terapia, de modo a cambiar sus mundos, como ya sucede en algunas de las nuevas terapias de comportamiento y terapias feministas.

Palabras-clave: terapia, contingencias sociales, salud mental, lenguaje en terapia, Jung, patriarcado, activismo como terapia.

Nota:

Declaramos que não há conflito de interesses na produção do presente trabalho. 
Analysing more thoroughly the role of social relationships and other human environments in determining human behaviour does not produce a new brand of therapy, and there are two chief reasons for this. First, such analyses also lead us to re-examine both the therapy situation itself as a by-product of late modernity and its purpose and usefulness (Guerin, 2017a; Rose, 1992). The second reason follows directly from the first: modern forms of social relationships (since the late 1800s) have led to an enormous reliance on language use (verbal behaviour, discourse) as the primary or sometimes sole means of attempting to change clients' lives and this is currently putting limits on what can be done for implementing change.

Putting these together: once we understand how much social and societal relationships underpin both our life conflicts and our uses of language, it is clear that traditional 'therapies' need to stop relying so much on talking and make more changes directly in the client's environment or world because that is where the conflicts are. Ironically, this also includes taking the clients' language use out of the office because clients' discourses are shaped in their external material social worlds rather than 'inside' them, and psychotherapies are not currently engaging with those who shape the clients' language. We need to move from psychological- or individual-focused therapies to making changes in the client's environment, where 'environment' includes their social, political, patriarchal, discursive, economic and cultural contexts (Guerin, 2016a). The new forms of ( $3^{\text {rd }}$ Wave) behaviour therapies are moving more towards this but this paper aims to help that along, and show how analyses of the sociological and cultural shapers which influence the client's world can be included.

In this paper I will (1) outline further what is added when making a broader contextual analysis of therapy compared to the behaviour- or functional-analytic models, (2) outline three things such analyses tell us about traditional therapy settings, (3) illustrate all this by re-analysing one of Carl Jung's case-studies, and (4) suggest what we can learn to develop better interventions which help people and communities deal with their life problems which are out in their many environments.

\section{What can we add in a contextual analysis to understand mental health and therapy?}

When we add a more thorough contextual analysis of human behaviour onto the early beginnings of behaviour analysis (Skinner, 1953, 1957) and the current functional-analytic models, several new things emerge (Guerin, 1994, 2004, 2016a, 2017b):

- There is an enormous impact of social relationship contexts in determining all behaviours of adult humans (Guerin, 2001, 2016b)

- Social relationships are additionally important because they form the material basis (reciprocity as the shaping by consequences) of all language use and so, just as discourse analysts do, we must include better analyses of social and societal relationships alongside language analyses and no longer just refer to 'generalized social reinforcers' (Barnes-Holmes \& Hayes, 2003; Guerin, 1994; McEnteggart, Barnes-Holmes, Hussey \& Barnes-Holmes, 2015; Skinner, 1957)

- A person's external environment, context or world shapes their behaviour but this must include all the contexts which shape and constrain them: social, patriarchal, economic, cultural, historical, discursive, and their opportunities

- We can begin to analyse how societal events shape the behaviour of individuals (Fromene, Guerin \& Krieg, 2014; Guerin, 2017b; Guerin \& Guerin, 2012; Guerin \& Ortolan, 2017)

- To change a person's behaviour, we must change their environments but this also includes many more contexts than are normally considered in behaviour analysis

Some of this is certainly implicit in early behaviour analysis (Skinner, 1953, 1957) but the implications were not drawn out sufficiently and more detailed analyses were never made of how social relationships and other societal structures impact on behaviour. For the purposes of this paper, I will focus here on just three implications of all this for mental health and therapy which will become important later, which can enhance the methods of recent behaviour analyses. 


\section{What are 'mental health' behaviours?}

Elsewhere I have argued that events in a person's life are primarily labelled as 'mental health issues' when we cannot easily observe the bad situations in their life which have shaped those behaviours (Guerin, 2017b). In this way, all those behaviours which we label as 'mental health behaviours' (see Table 4.4 in Guerin, 2017b for a list) are no different in principle to any other behaviours found with humans-they all arise from situations in life which shape those behaviours through material consequences (Johnstone \& Boyle, 2018; Schwartz \& Goldiamond, 1975). The main differences for those behaviours which get labelled as 'mental health issues' are that (1) they are behaviours which lead to conflict and stress for the person, (2) they have become chronic because of the person's stable external situations, and (3) the events which have shaped those behaviours are not easily observed by either client or therapist (cf. 'invisible contingencies', Ruiz, 1998).

There are many ways in which contexts or material consequences for behaviour can be hidden, thus leading to pseudo-explanations in terms of 'mental health' causes and diseases. Some of the ways contingencies are 'invisible' are:

- Not enough time has been spent observing all that person's behaviours and actions; even if you have good reasons for this-it takes too long, your boss will not allow extra time, your research needs to finish quickly-you will still miss out and will have to resort to averages or abstract theorizing

- Not enough time has been spent observing those behaviours in context rather than talking about those contexts, and this includes people observing their own contexts in life

- Language is just a behaviour shaped by our language communities, so where language use (including thinking) is prevalent in a context, that social control of language is very frequently difficult to observe without a lot of effort

- There are historical events and contexts that you have not observed or have not thought to find out about
- There is something that the person has successfully avoided or escaped from in the past by doing what they are doing, and you cannot observe that because it does not actually occur anymore (since it has been successfully escaped or avoided)

- There are key elements of the context for behaviour that are not present in the current situation so you cannot see them without spending more time in their world and exploring history

- There are key elements of the context shaping behaviour that the person has kept secret or is hiding for other contextual reasons (such as they will be punished by others, or repression)

- There are key elements of the context for behaviours which simply do not fit into (your) ordinary experience and so are not observed even though they potentially could be, and this includes the societal structures which shape and limit what we can do: "sociology is the study of the way in which humans are shaped by things that they don't see" (Richards, 2014)

\section{Analysing modern therapy settings: Why} are we sitting in an office when the client's environments are out there?

The second point we can learn from looking at the broader contexts for behaviour is how to analyse the contexts of modern therapy themselves. Put in context, 'mental health' problems are now primarily dealt with by professionals who are strangers to the client, and are in stranger or contractual relationships (Guerin, 2016a). This means that there are bureaucratic limits on what can be done and any reciprocity to maintain the relationship will be through the exchange of money. With some generous, kind exceptions, therapy usually ceases when the money runs out.

There are more subtle and convoluted effects of the modern therapy context, however. The stranger or contractual relationships mean that the therapist has limited ways to influence the client, since many common life methods-such as using friends and family to influence someone-are not available (Guerin, 2016a). Therapists are also usually not allowed to have friends and family join the client in 
their therapy because of bureaucratic and ethical issues, and therapists are not supposed to become close friends with clients. Therapists also cannot usually go out into the world of the client and work on intervention strategies, again with some exceptions, even though social workers do this on a regular basis (Guerin, 2017a). What this means is that the settings for modern therapy exclude many of the common and successful ways that people intervene and influence each other in life.

These sorts of constraints mean that the use of language as a way of changing someone's behaviours has become almost the sole way of both learning about and documenting the client's world and issues, and also for carrying out any interventions. Even having the client do behavioural homework, a common method used in most therapies (Guerin, 2017a), relies on the client promising to follow rules or follow instructions - which are all about the use of language. What this means is that within current therapies there is a huge investment in trusting language use as an intervention, and an enormous focus on how to get language to work and do things to people. This is very clear in all the $3^{\text {rd }}$ Wave therapies which are pushing the limits of how language in a modern therapy setting can be used to influence people to change their external environments. Such new therapies are greatly extending what can be done, and some allow outside contact with their clients, but at least some of the above limits on traditional psychotherapies are still present. This is especially pressing given that the aim is to change the client's behaviour by changing their environments.

The problem with this is that using language to change people depends on the social relationship, its forms of reciprocity, and history of the two people involved (Guerin, 2016a, 2017b). Just saying words does not affect people or the world; it is the history of resource exchanges and reciprocities (contingent consequences) which lead talking to do something to people. Just saying "Can you give me your bag?" will not influence a stranger because strangers require reciprocation, usually of money (Guerin, 2016a). Saying the very same words to a close friend is likely to be more successful not because your friends are 'nicer people' but because of your history of reciprocity and exchange (of more than money). So just this point alone means that the use of language as an intervention in traditional therapies will not be very successful since the stranger is paying the therapist, and any other reciprocities will be fixed inside the setting only and likely to be weak once outside the setting.

There are many other problems which arise from such an enormous reliance on language use. One other problem is that the client's use of language is shaped by the real people and audiences in their own life (strictly, shaped by the material consequences of interactions), and for therapeutic interventions to really be effective the client's 'discursive audiences' might also need an intervention. The sole use of language also means that much therefore relies on the client promising to do things during the week between sessions, and most of what they 'take' away from a therapy session is the training of words which the therapist has tried to shape. The client's language audiences at home might easily reshape all this.

Unfortunately, this strong focus on languageas-intervention will not be changed easily or soon, however, since my argument is that it does not arise from any choice of therapists but has been shaped by the contexts of modernity in which we all live. What is needed are broader analyses of the functional effects of societal and cultural environments, and finding ways to get change through individual and language-based sessions. The $3^{\text {rd }}$ Wave Therapies are best placed to do this.

\section{What happens when you cannot observe or describe what is shaping your life problems?}

I now want to bring these two points together for a crucial point of this paper. We have learned so far: (1) the shapers of what we call mental health issues are usually 'hidden' or else they are not defined as 'mental', and (2) the use of language in therapy is currently the dominant way to change people's behaviours. These lead to a third problem for traditional therapies.

Human behaviour is complex and there are many situations in life for which the determining situations and consequences are difficult to see. I have already suggested that 'mental health' behav- 
iours are like this by definition, and indeed the term 'unconscious' is used by some to mean this inability to observe and name the contingencies, as we shall see below. In everyday life, however, when we are asked to explain our own behaviours it is common that we have no idea where they arose from, because the shaping from societal, patriarchal, economic and other environments which shape us, are not easily observed. When this happens, however, we have a range of other discourses to cover us. These discursive strategies include the use of mentalisms, abstractions, replying with questions, personifications, the use of 'emotive' language, and distractions (Edwards \& Potter, 1993; Guerin, 2016a; Potter \& Edwards, 1990).

[There are also non-discursive responses in everyday life when you cannot respond, but we are considering here just normal therapy situations in which language use is predominant. Such non-discursive responding includes 'emotional' behaviours other than 'emotive language', poetry, painting, music and other forms of art, and non-language use forms of distraction (Guerin, 2019).]

The point I wish to make from this is that when we cannot observe or name the complex contingencies shaping our behaviour then there are numerous discursive strategies we have learned for handling this, if we are forced to talk about it nonetheless. A typical situation of this in everyday life is when we are asked 'why' questions, since we usually do not know why we do things. But, regardless of this, we have a plethora of ways to answer why questions. "Why did you start buying incense and burning it?" "I dunno, just had this sort of hippy thing come over me I guess." If asked, "Why did you do that?" we can always answer: "Oh, I just decided I wanted to do that", "Oh, I guess I must really like doing that", "Oh, just something someone said at work", "I'm not sure but it was good." Such mentalistic discourses are not about providing accurate descriptions of the person's world and contingencies, but these 'explanations' all suffice for everyday conversations. The evidence is that the discourses used to answer such questions are not like actual reports of what happened or what was observed, but primarily discourses which are acceptable-in-a-conversational-context as explanations (Bem, 1965; Guerin, 2016a; Nisbett \& Wilson, 1977; Mills, 1940).
When we get to therapy or research, however, we can use such discursive strategies only up to a point because for many 'mental health' issues we really do not know what happened, as I argued earlier, since they have been shaped by our societal environments. After that, the person can say no more and some therapists might claim they are showing signs of 'unconscious repression'. But in all of this, what I am saying is that for a large number of our own behaviours we simply do not know what shaped them and this is more common for those which get labelled as mental health issues. In the more difficult situations, we might not even be able to describe what happened, let alone say what contexts brought it about. Ironically, just as behaviour analysts have filled this gap by resorting to the term 'generalized social reinforcers' (as done by Guerin, 1994, and Skinner, 1957), psychiatrists often sidestep this problem by using 'generalized' depression or 'generalized' anxiety (Guerin, 2017b).

What this all means is that when a person is clear that something has happened to them or that they have done something with consequences, but when they cannot report what those are, then there are common discursive strategies for handling this. This is extremely relevant to this paper because of (1) the description given earlier of mental health behaviours (those with hidden shapers) means this will be ubiquitous in therapy situations, and (2) the reliance on using language in modern therapies means that the therapist cannot go and witness or even experience the same contingencies themselves in the client's world.

In summary, the idea which I am suggesting in this paper is that therapy primarily uses language to deal with mental health issues, and these are frequently issues for which the client cannot say what contexts have led to their behaviour being treated, and this means that we should discover traditional therapists also resorting to the everyday discursive strategies of finding some reason or theory for why the problems are there. That is, therapists (Guerin, 2017a) will not know what is going on for many of their clients' problems, since they do not go into the clients' worlds to find out, and so the therapists' discourses will show examples of mentalisms, abstractions, replying with questions, personifications, the use of 'emotive' language, and distractions. 
The point I will develop next from this is that the changing nature of social relationships in modernity has produced an even larger number of new ways in which society shapes our behaviours and which we cannot observe or name because strangers and not family are involved. These societal forces are the shapers of some new mental health issues in modernity (Guerin, 2017b). I will then try and illustrate all these points below by tentatively recontextualising a case-study by Carl Jung (1917), who worked at the beginning of modernity. But to put my argument so far into a clear form:

- when the issues around life bad contexts and conflict situations are not easy for anyone to observe or describe (neither the contexts nor the shaping consequences)

- as is the case for what we categorize as 'mental health issues' (otherwise a carer could fix them)

- and when you are only relying on talking about all this (as happens in most traditional therapy) rather than observing or intervening in context

- then just like everyday life, the 'explanations' of both client and therapist will have a strong emphasis on mentalistic and other abstract uses of language, and 'emotive language' (Edwards, 1999; Frith \& Kitzinger, 1998; Hochschild, 1979; Howard, Tuffin \& Stephens, 2000)

- as has been the case for most psychotherapies since Freud, including Freud's use of new mentalisms and Jung's notions of 'complexes' and 'archetypes' which we will examine below as examples

- and this has arisen because since the late 1800s new societal changes (capitalism, bureaucracy, neo-liberalism) have re-shaped our forms of social relationship and made the contingencies more difficult to identify, thus shaping new forms of 'mental health' behaviours and new abstract, mentalistic 'explanations' for them.

\section{The beginnings of 'mental health' and therapy}

Both before and after Freud, there was one way to discursively 'explain' the new 'mental health behaviours' which seemed to have no obvious 'causes', and this was to attribute them neither abstractly nor mentalistically, but to a 'physiological substrate'. This was, in fact, really abstract anyway since these 'substrates' were not physiologically identifiable (then or now). Such explanations looked physical, concrete and scientific but had no substance and were once again merely uses of abstract discourses and neurological metaphors.

While most physicians of that time believed or promulgated such neurological metaphors, what Freud, Breuer, Janet, Charcot and others did differently, and which they explicitly wrote in their books, was to admit that they could not find a physical basis for the complaints they tried to treat and that these symptoms were something new (hysteria, dementia praecox, etc.). It is important to understand, therefore, that new behavioural phenomena were occurring for these early medical people to treat. Their own writings demonstrate that they were uncertain and making things up on the run (see the case of Miss Lucy R. in Breuer \& Freud, $1895 / 1974)$. My point will be that the changes in society at that time were producing new forms of hidden societal stress, conflicts and pressure, resulting in these new 'symptoms' which no one could understand, and they could not be side-stepped any longer by using neurological metaphors.

These new 'hidden' conflicts were a result of changes in modern society which led to major changes in social relationships. What we then see with Freud, Charcot and others, is the rise of their own new discourses which suddenly include new types of mentalistic and abstract 'explanations' because these new modern forms of 'hidden influences' could no longer fit, even using abstract explanations of brain 'substrates'. Put this way, Freud's major discovery was that there were new life conflicts which people could not talk about, but unfortunately, he handled this by building mental metaphors (the unconscious, ego) rather than going into these clients' worlds to observe what was happening in their new 
social and societal relationships. So, in the end, he resorted to mentalisms and abstract discourses, as we do in everyday life, to 'explain' these new and very traumatic changes in societal relationships. Such metaphors were elaborated and multiplied until much later on behaviour therapies began to pull this back to what is actually observable or not. Now I wish to include more of the societal and other hidden environments to these analyses.

\section{Re-analysing one of Carl Jung's case-studies}

I now want to illustrate most of what has been suggested above while turning some of Jung's ideas inside out-from internal to external. I will focus on one case study and try and show that the client's 'issues' were in her external societal situations (patriarchy) and not in her head, but that the contemporary changes in patriarchal contingencies were hidden or invisible because of the vast changes in societal relationships at that time (Riuz, 1998). I will also try and show that because her 'issues' were not tangible or easily observable sorts of problems, they were labelled as 'mental health issues' and 'explained' by Jung abstractly and mentalistically, and through 'emotional discourses': internal complexes, feeling tones, and 'archetypes'.

When reading Jung, we therefore need to rethink most of his main concepts (verbal constructions) with a contextual discourse analysis of his uses of language (cf. Lacan, 2006/1953). These are brief 'translations' into more observable contingencies but will suffice here:

- Unconscious: Saying that a person 'has' an unconscious means that there are many contingent relations between doing and outcomes in their life but the person cannot name or talk about these. This consists of all the trained or shaped behaviours learned by a person through their lifetime. Of most relevance to psychoanalysis and all therapies are the language responses which make up the bulk of the discussions about the unconscious (cf. Lacan, 2006/1953). But as we will see below, this is misleading because the material societal shaping, such as pa- triarchal structures, is not recognized and so given a metaphoric explanation instead.

- Conscious: In any situation we are in there will be multiple learned uses of language (a more apt description is 'discourses' since they are not there as single words but as learned conversations or narrative 'extracts') because through life we over-learn our uses of language. The conscious refers to any verbal behaviour or discourses in any context whether said out loud or not. Depending on the situation, one or more might be said out loud but this is determined by the situation, not by an inner self or ego.

- Raising unconscious contents to consciousness; individuation: This means being shaped to act or say things which have previously been hidden or punished, or saying things in a new way which has better consequences for the person-even if metaphorical. A better future use of this term might be being able to articulate, or be aware or mindful of, the societal structures shaping one's behaviour.

- Personal unconscious: This refers to all the ways we can speak and have discourses about our own life situations which are tangible, observable or easily 'speakable', but which for many reasons cannot be said at the time or are punished so they are not there as an available thought (which is therefore contradictory and stressful for the person).

- Collective unconscious: This means the ways we have learned to speak, our discursive strategies, when we are unable to say what is happening, and which occur in many life situations in which our conflicts are neither tangible, observable nor easily 'speakable' and no words can say what is happening anyway. In such cases, as outlined earlier in this paper, we have still learned ways to answer questions (especially abstract or mentalistic) or to respond without language ('emotional' behaviours, arts). Because these were learned and commonly shared discourse strategies (abstraction, mentalisms, etc.), they appeared to Jung to be 'collective' manifestations of something inherited. 
- Complexes: These are a mentalistic and metaphorical way Jung and others used to refer to external conflicts in a person's world, and the discourses about those conflicts. Because these are discourses about conflicts, many will have been previously punished and no longer 'conscious' in those situations anymore-they cannot be talked. But because they are still learned behaviours they can affect current behaviours whether or not they can be named or talked about.

- Feeling tones: For Jung this refers to other nonlanguage responses to conflict when there are no discourses available; "Things feel bad but I am lost for words"; most often these shaped 'emotional' responses are about social conflicts; something has a feeling or emotional quality usually means it is about a novel or conflictual social relationship situation which has no easy words. So, when many conflicts in a person's life are not observable then we might observe them 'crying for no reason', a common DSM behaviour (Guerin, 2017b, Chapter 4). They have a 'complex' (a life conflict) which is bad and if they cannot name this then they might have 'emotional' responses. Jung's 'complex feeling tone' is really saying 'bad and painful conflicts which cannot be spoken'.

- Archetypes: When external conflicts in a person's world arise from conditions which cannot be easily named or discoursed, the person uses abstract, mentalistic or personification forms of language to answer questions. Jung noticed that there were some typical or common cases of this happening but attributed these to a 'collective part of the mind or brain which lay in the unconscious, and he labelled these archetypes. "I have this complex of negative unknown forces that are affecting me but I cannot describe them; but it seems as if a giant mother figure was bringing about all these pressures on me." These are learned discourses, generalised across people and settings, and have no specific target issue or target person involved; putting these into words or discourses (talking, thinking or dreaming) becomes abstract, artistic, poetic, metaphorical, imaginal, musical, or just plain vague. Both the conflicts and the discourses which attempt to talk about these conflicts are actually externally driven to the person, but Jung's metaphor spoke of them as arising from an internal 'collective unconscious'.

\section{Some societal background context to Jung's case study}

At the end of 1800s, through the 1900s, and until now, there was a series of major changes in western societies, which had one effect of changing human relationships from being strongly family-based to being strongly stranger- or contract-based. This meant that strangers gradually became a larger part of living, and more and more of our necessary contacts in life (exchange relationships or contingencies) were with strangers rather than family. This change is now almost complete and most of our lives is now full of interacting with strangers rather than family. It is not that family are better or worse than strangers in negotiating our lives, just that they have markedly different social properties and consequences which change the way we can run our lives. For example: our families know each other, but our different groups strangers do not; we get resources through family from obligations, but from strangers by money with no further necessary obligations (more in Guerin, 2016a).

The relevance of this shows in many life areas of the woman in Jung's case-study, but I will just consider here the form of patriarchal or male-dominated control she will have learned throughout life. Before this point in time, patriarchal control was enacted through the male head of the family, and the sorts of families that could send their daughters to psychiatric therapy had powerful fathers who were given control of family members by society itself-these men were not necessarily born strong but were privileged to be shaped that way through life. If a daughter behaved 'badly', other men in society would not necessarily rebuke her but they would certainly rebuke her father. He therefore had almost complete control, in the eyes of the law and all society, over what his daughter could do and how he would punish his daughter if she strayed. Women's lives, therefore, were controlled strongly by their fathers until about his time.

But around the time of Jung's early work, this paternal enactment of patriarchy was weaken- 
ing and control was being taken over the shaping of women's lives by male strangers; women could get out of the family home more often, perhaps, but they were being controlled (shaped, censured, punished, reported to authorities and parents) by men they were not related to and whom they might not even know. Control gradually moved into the hands of abstract, generalized men (the 'generalized other' in sociology) and away from the actual father person. This also shows in the abstract (and even mythological) way in which Freud brought 'family' into his therapy. Clients were having major problems they could not describe (therefore called unconscious), in addition to problems with the physical parents which they could describe because there were concrete acts and people. Freud gradually changed to 'explaining' mythologically the conflicts which could not be solved, in terms of abstract themes of Oedipus, for example, as well as ego, id and superego. This was no longer the physical parents controlling his clients' lives but the 'superego', a generalized other (i. e., a stranger patriarchy).

[Freud shows an interesting mixture of client problems due to both powerful fathers and due to 'walking in two worlds'-where there were both powerful fathers and powerful strangers shaping their lives. Jung also dealt with the former cases but did not discuss or write about them much but concentrated on clients who had already dealt with these problems but still had problems with no source. I am suggesting that 'mental health' today is primarily about hidden problems with strangers and society and that family is less of an influence. Current society also makes it easy for most people to exit their families if there are difficulties, which was problematic for most people in Freud's day.]

This change has now almost completely played out. In our current times, women are still being controlled and censured by the privileges allowed males, but this arises almost exclusively through strangers, with fathers frequently only a weak source of control. The important change for this paper, is that those who are now controlling women through male patriarchy are strangers, unknowns, nameless people, bureaucrats, and very much abstract entities as we see on media. We can no longer blame or explain the specific, concrete, individual fathers for their daughters' restricted behaviours because women are now being controlled to behave in certain 'female' ways by nameless and abstract strangers. The effects are still very real, disempowering and very frequently painful for women, but there is no longer a tangible target with whom to intervene and stop these conflicts; there is no face for those who now are limiting and ruining women's life opportunities. They are more hidden now as parts of the environment which strongly shape our behaviour.

What this contextual analysis is saying, therefore, is that the life conflicts for Jung's client were external to her and not 'inside her' as Jung thought, were very real, involved restrictions in what she could do with her own life as a female, and involved behaving in certain ways or else having to spend a lot of time and effort disguising what she did but always with the threat of punishment if found out. However, the new change is that this is no longer coming from an easily named source-such as her father, both her parents, or her older brothers-but from a 'generalised other' (Mead, 1934), an abstract bureaucratic system, or 'men in general but not any specific man'.

Putting this together with my earlier argument, then, says that in such situations when a woman is asked to describe her conflicts and stress, this is nearly impossible. They know correctly that there are real conflicts, stresses, or pressures put on them from patriarchy (and other societal structures), but they can neither observe nor name what or who is doing this to them. If forced to talk or comment more (such as when urged by their therapist), they can certainly come out with a lot of words, but these words are not describing what is actually going on in their worldthe words will be those discourses identified earlier in this paper as ones we have learned to use when we cannot talk about something. "Emotional' behaviours are likely to occur (crying for 'no reason'), but because of the therapy setting's emphasis on talking and language interventions, we will usually not witness within therapy sessions the common musical, artistic, poetic, imaginal and other non-language responses to unspeakable conflicts which are found in everyday life, unless specifically requested by the therapist (hence music- and art-based therapies). Most therapies do not let the client 'sing the blues' for an hour. 
For Jung, my analysis is that this is exactly what he did because he did not understand the shaping of her 'dysfunctional' behaviours either. He talked to her about them as abstract and mentalistic theories: 'archetypal' figures or 'archetypal' situations. His client could not speak or describe the conflicts in her life because they were societal, anonymous and hidden. But Jung translated these into internal, mentalistic features of an 'inner' person and of unconscious conflicts taking place within their 'psyche'. This followed because the discourses (talking, thinking and dreams) reported by clients were observed by him to become vague, to use metaphorical content, to prefer imaginal and artistic portrayals, and to use standard versions of vague and abstract discourses. However, the point is that these conflicts arose in very concrete and real societal contexts, external to the client, but which could not be named or even observed. Such external situations, therefore, produced these metaphorical characterisations or personifications labelled by Jung as archetypes.

However, while we can agree on the observed parts of all this, Jung's explanations are unnecessary and betray the easy way psychologists and psychiatrists put everything into theoretical 'inner' worlds. What Jung correctly observed across many clients (mainly female notice) was that: (1) his clients produced emotional behaviours 'for no reason' and felt 'over-powered' by forces they could not name; (2) their discourses or learned verbal repertoires (talking, thinking and dreaming) became more abstract and generalized and more like 'mythological' thinking; (3) they stopped speaking in terms of specific people in their life; (4) they stopped reiterating life events which were specific, clear and already known; and (5) this gave both client and therapist difficulties with analysis.

These basic observations seem clear and my analysis has tried to put these in contextual or behavioural terms, which newer behavioural therapies can build upon. But Jung claimed that the abstract entities and situations reported under these conditions (archetypes), were 'collective' and existed in everyone's 'unconscious'. He even said or hinted that such unconscious entities (for us, they are just fictional discourses in his therapy) must be inherited in a very Lamarckian way-the image or archetype of the 'devil' is supposedly passed down to people in some core parts of the human brain. $\mathrm{He}$ also had the idea, along with many of his contemporaries, that this sort of thinking was 'primitive' and came from the early days of humans and still exists in 'primitive tribes' around the worldhe strongly believed the false 'ontogeny recapitulates phylogeny' line of reasoning.

So, Jung's (and others) mistake was to wrongly assume that because the clients' discourses became metaphorical and abstract, there was no real concrete substance to them. We can, however, provide a simpler contextual or behavioural analysis of the same basic observations: that clients were producing shared abstract explanations of very real societal structure conflicts which is now the way most modern behaviour is shaped. Just because the client cannot report concrete details does not mean their issues were not concrete and external to them-that is the nature of modern societal structures built on multiple stranger relationships if one reads sociology, social work and social anthropology.

But what are these new, modern, hidden or 'unspeakable' conflicts and pressures from modern life? As mentioned above, in modern society, starting around Jung's early period (1917), people's conflicts and pressures in life became more abstract because of involving more and more strangers (Kafka's The Trial was written in 1914-1915). We do not have easy discourses to describe these sorts of abstract societal conflicts and pressures but we do have many discourses and images which can instead portray the abstract nature of our new concrete life conflicts. These shared discursive strategies are learned and not inherited.

Such discourses are also not 'primitive' but are indicative of the ways any human beings talk when trying to talk about something real but which is not known clearly and not easily 'speakable. While such ways of talking do occur in Indigenous groups around the world, this is only because their ways of living and their overall ecologies also have many unknowns, but these are hugely different ones to our societal contingencies which have this property. Their very different 'unspeakable contingencies' arise because they live close to 'nature' which does unpredictable things which shape their behaviours, and they do not live in our western, 
predictable, time-based and risk-free constructed worlds. So, such forms of thinking and talking are certainly seen frequently in 'tribal' lives, such as myth-making and animisms, but these are only in some parts of their lives and are there, ironically, for the very same reason Jung and Freud resorted to talking about egos, ids, archetypes and complexes (Levi-Strauss, 1966). When talking about the wellknown, observable and tangible parts of life, on the other hand, 'tribal' peoples do not display these abstract discourses and are entirely pragmatic, just as we are in the western world (Costa \& Fausto, 2010; Graham, 1993; Ingold, 2006; Turner, 2009; Viveiros de Castro, 1992, 2015).

So, Jung was not correct that the unconscious was full of hidden 'primitive' ways of speaking' which arise from deep in the clients' brain layers. Rather, when his clients could not talk about these new 'un-speakable' societal conflicts and pressures in their modern life-very different to the 'unspeakable' conflicts of Indigenous tribes-both the clients and Jung resorted even more to abstract forms of discourses to cover themselves. But these discourses are not descriptions of anything. They are responses to not being able to describe anything, and only the language forms were relevant to Jung because of the language base to the new therapies being developed at this time.

Having given some background to the historical setting of Jung's analyses and why they overstretched their bounds of acceptable explanations, I will apply these basic arguments and re-frame what Jung said in his case-study. Nothing I will suggest is a certainty, however, since we only have Jung's limited description of this client and her world. My suggestions are only possibilities (Guerin, 2016a). But there are many passages which strongly suggest we can fill in some (possible) details which Jung did not cover and did not explore further with his client. In some cases, he would have needed to leave his office and go into this client's world, or the world of any early $20^{\text {th }}$ century female, to get a better understanding. Hence, there are feminist critiques of Jung's understanding (Gray, 2008; Kulkarni, 1997; Rowland, 2002).

\section{Background contexts for Jung's client}

The case-study involved a female client who presented with depression. She was in a relationship with a woman in which she dominated the other woman, and they had regular conflicts which was also a presenting problem. This was presumably a homosexual relationship although Jung does not say this explicitly. The client saw herself, however, as feminine and was apparently surprised when Jung pointed out her 'masculine' appearance.

[It should be noted that through this and other case-studies around the same time, Jung treated homosexuality as something which happens but which needed to be changed in order for the person to 'grow up'. This would be treated differently now, hopefully.]

Both women were also 'nervy' and artistically inclined, but took few risks. While the client was shy and introverted, Jung reports finding a 'frivolous' streak in her which he said was repressed, however. Her story was that she had greatly admired a friend of her mother (Mrs X) who became frivolous and 'gay' (in the traditional sense) after her husband died, and who even had a fling with an artist who 'fascinated' Jung's client, but Mrs X died early from cancer. This apparently scared the client and she gives a socially acceptable 'explanatory' discourse (as discussed earlier) that she 'believes' this 'gay' side of Mrs X led to the cancer and killed her. She is 'therefore' fearful of 'letting go' in these frivolous ways, scared that she will engage in 'immoral' behaviour if she does. Jung's suggestion was abstract: that remaining in a relationship with her female friend was a way of preventing herself giving in to her repressed desires (with men, he claimed) and therefore leading to disaster (according to the client's story that is).

The client mainly focused her therapy goal around 'moving on' in her life and leaving the relationship with the woman, but the therapy seemed to go around in circles and not progress according to Jung. Both women seemingly spent a large part of their lives together and their fighting was from 'irritability' due to constant contact: "their mutual relationship is too intimate and excludes too 
many of the other possibilities of life". But neither was able to break from the other. Their interactions and fighting seemed to consist mainly of talking and words, rather than anything more physical or active. So, they stayed together, even though both wanted more out of life, but they could not say why. Later Jung revealed that, "The patient does not know any man who means anything special to her, apart from myself", showing just how much the two were living an isolated existence which, I will argue, was also shaped by the patriarchal constraints on them but they and Jung were unable to analyse or articulate this.

Finally, what we do not know. We learn nothing of the economic context for this client (and her friend) even though that could be important in several important ways. We learn little of their family backgrounds and status. It could be inferred from this that the client's problems were not a direct result of her father or this would have emerged. We also have no idea of how this therapy concluded and what happened in the client's life thereafter.

\section{The analysis of Jung's case-study}

My social contextual analysis of this case is contained in Table 1, which shows where patriarchal shaping and constraints on the client occur. Table 1 presents some sample quotes from Jung (1917) about the case in the first column and some contextual analysis remarks in the second column. The contextual remarks are aimed at highlighting possible examples of how the client was really in conflict with the patriarchal shaping of her behaviour and life (almost exclusively by restricting her behaviours) but because this was not through her actual father she is unable to give exact descriptions or reasons for why things occur. The examples show the reality of the pain she is suffering, since societal or strangerbased conflicts are still bad and stressful pressures which shape behaviour, whether or not they can be seen or articulated. It also tries to show possible ways in which both the two women staying together and their conflicts also arose due to hidden societal shaping of their behaviours. The second column also tries to show where and when Jung begins talking about her 'explanations' and other discourses in terms of his own abstract, mentalistic and metaphorical neologisms of complexes and archetypes.

Table 1. Analysis of Jung's (1917) case-study, with sample quotes and a social contextual analysis of the client's struggles in term of the patriarchy preventing her life moving forward and the use of abstract, mentalistic and metaphorical discourses by Jung to cover his ignorance of this.

Quotes from Jung (1917)

[123] A woman patient, who had just reached the critical borderline between the analysis of the personal unconscious and the emergence of contents from the collective unconscious, had the following dream:

She is about to cross a wide river. There is no bridge, but she finds a ford where she can cross. She is on the point of doing so, when a large crab that lay hidden in the water seizes her by the foot and will not let her go. She wakes up in terror.

Associations:

[124] River: "Forms a boundary that is difficult to get across-I have to overcome an obstacleprobably to do with the fact that I'm progressing so slowly-l ought to reach the other side."

\section{Social contextual analysis of the client's possible life situations}

This means that she can observe and talk now about all her regular conflicts and bad situations in life but there is something more pressuring her which she cannot easily put into words.

We can treat the dream as we would any thoughts or words, arising in context from the pools of discourses this person has been trained in through her language learning and her life experiences of doing, talking and thinking.

She says that her therapy is working slowly and something is not being addressed. 
[125] Ford: "An opportunity to cross in safety-a possible way, otherwise the river would be too broad-in the treatment lies the possibility of surmounting the obstacle."

[126] Crab: "The crab was quite hidden in the water, I did not see it before-cancer [German $K r e b s=c r a b]$ is a terrible disease, incurable-1 am afraid of this disease- the crab is an animal that walks backwards__ it caught hold of me in a horrible way and I was terribly frightenedwhat keeps stopping me from getting across? Oh yes, I had another row with my friend [a woman]."

[127] There is something peculiar about her relations with this friend. It is a sentimental attachment, bordering on the homosexual, that has lasted for years. The friend is like the patient in many ways, and equally nervy. They have marked artistic interests in common. The patient is the stronger personality of the two. Because their mutual relationship is too intimate and excludes too many of the other possibilities of life, both are nervy and, despite their ideal friendship, have violent scenes due to mutual irritability. The unconscious is trying in this way to put a distance between them, but they refuse to listen. The quarrel usually begins because one of them finds that she is still not sufficiently understood, and urges that they should speak more plainly to one another; whereupon both make enthusiastic efforts to unbosom themselves. Naturally a misunderstanding comes about in next to no time, and a worse scene than ever ensues. Faute de mieux, this quarrelling had long been for both of them a pleasure substitute which they were unwilling to relinquish.
Still hopeful that treatment can help her although something is stopping her progress.

1. Reiterates that she is in pain, and there are things in her life she cannot fathom.

2. From wondering why she cannot move forward in therapy and life, she mentions a new fight with her friend.

\section{Analytical (causal-reductive) interpretation:}

[128] This interpretation can be summed up [by Jung that is] in one sentence: "I see well enough that I ought to cross the river (that is, give up relations with my friend), but I would much rather that my friend did not let me out of her clutches (i.e., embraces)-which, as an infantile wish, means that I want Mother to draw me to her in the exuberant embrace I know so well." The incompatibility of the wish lies in the strong undercurrent of homosexuality, abundantly proved by the facts.
1. 'nervy' is not explained but as a woman of that era she had all sorts of patriarchal and more general economic (status) constraints on what she was allowed to do and say; and there were opportunities she could not follow as a woman for fear ('nervy') of punishment.

2. "mutual irritability" because society has forced them to be private and spend too much time alone; other options involving men and marriage are obviously too anxiety-provoking because of the societal demands that would be made on them

3. It is possible in that era that she might have wanted to pursue an artistic career but this was not allowed (highly gendered except for women of wealth)

4. This is not the unconscious trying to do this, but the situation they are in considering the larger societal focuses at play on them

5. Their relationship is clearly very much about language use (quarrelling, speak more plainly, misunderstood and urges the other) and this puts limits on how well they can live with each other
[129] This interpretation is a severe depreciation of the patient's exalted ideal of friendship. To be sure, at this point in the analysis she would no longer have taken exception to such an interpretation.... Such an interpretation would have been impossible at the beginning of the treatment, because the unusual prudery of the patient would not under any circumstances have admitted anything of that kind.
1. Jung seems to be treating this as a simple personal problem, whereas the societal constraints affect us all and there is no division between personal determinants of behaviour and societal (or Jung would say collective unconscious) determinants of behaviour.

2. She and her friend still have language fights and she knows (is conscious of) that she needs to give up the relationship as it is. But it is her wider societal constraints which leave her no alternatives because there are restrictions and punishments attached to any other things she might do (except marry a man and have children, perhaps). This produces anxiety about doing something new.

3. The client has said this now many times, so there must be more involved which she and Jung cannot name. Jung himself will go on to produce abstract language responses to the client's dilemmas rather than analysing for societal structures which might be the context keeping the two women together.

The social notion of homosexuality was not agreeable and she was unusually prude, according to Jung. This again reiterates that the client was very much responding to societal demands of what she should or should not be doing, at least in the responsive discourses she gives to people. Once again, this suggests strong stranger patriarchal pressures upon her which she has learned, probably over her whole life, and which is actually leading to the form and outcome of her relationship. 
[134] Here I was able to remind the patient of a series of earlier fantasies and dreams which had plainly shown that she too had a frivolous streak in her, and one which she always anxiously repressed, because she feared this dimly apprehended tendency in herself might betray her into leading an immoral life. With this we have made a further important contribution towards understanding the "animal" element; for once more we come upon the same untamed, instinctual craving, but this time directed towards men. And we have also discovered another reason why she cannot let go of her friend: she must cling to her so as not to fall victim to this other tendency, which seems to her much more dangerous.

[136] The story of this identification by no means ends here. The patient subsequently emphasized that Mrs. X possessed a not inconsiderable artistic capacity which developed only after her husband's death and then led to her friendship with the artist. This fact seems to be one of the essential reasons for the identification, if we remember that the patient had remarked what a strong and peculiarly fascinating impression the artist had made upon her. Fascination is a compulsive phenomenon in the sense that it lacks a conscious motive; it is not a voluntary process, but something that rises up from the unconscious and forcibly obtrudes itself upon the conscious mind.

This gives us another clue: in relation to her friend, the patient obviously plays the same role that the artist played with Mrs. X. Thus she unconsciously completes her identification with Mrs. $\mathrm{X}$ and her lover, and thus, in spite of all, she gives expression to the frivolous streak in her which she had so anxiously repressed. But she is not living it consciously, she is rather the plaything of this unconscious tendency; in other words, she is possessed by it, and has become the unconscious exponent of her complex.
1. Jung found a frivolous streak, but he claims this had been 'anxiously repressed' which here really means "societally squashed". That is, she had words and ideas about being frivolous but all those opportunities had been punished, by 'societal and patriarchal' forces in this case and not by specific people. The whole scenario would have been very different if it had just been her father or a particular teacher who had crushed her opportunities in life because she would have been able to talk at length about this clearly. Notice that Jung implicitly puts the blame on the client for not being frivolous, not on her context.

2. 'Dimly apprehended' means that she could not easily speak it anymore. 3. This is not a conflict of an "untamed, instinctual craving... directed towards men" but of normal life opportunities which have been restricted (threatened, punished) by un-seeable social pressures, and these consequences she has learned all her life.

4. "she must cling to her so as not to fall victim to this other tendency, which seems to her much more dangerous". This is again indicative of strong, gendered societal pressures she cannot name or put into words

1. The fascination is not "something that rises up from the unconscious and forcibly obtrudes itself upon the conscious mind." It is indicative that she can sometimes see and talk about the other opportunities she would have liked to have in life (like this artist has as a man), but even while talking this she cannot speak why it was not possible for her even though she knows it is not possible.

2. When thinking or talking about Mrs $X$ she can see artistic opportunities that are now lost, happy times which she is not achieving, and frivolous relationships with other artists (whether male or female) which she will never have. But the conflict she has is because she (accurately) cannot see what stops her.

1. No. There is no magic 'identification' process which drives her behaviour. Simply, she has always wanted to do what Mrs X and artist did, but cannot because she has not been allowed to do such things because of patriarchal forces she cannot observe or name.

2. "But she is not living it consciously" means that she cannot talk about it or even have those discourse as thoughts

3. If anything, she is the plaything of the patriarchal and other societal forces which have prevented her from doing things she might have wanted to do since childhood, but as a woman she could not.

4. "she is possessed by it, and has become the unconscious exponent of her complex" is an example of Jung not knowing how to speak of something and then issuing mentalisms to cover this. 
[141] We are now faced with the task of raising to the subjective level the phenomena which have so far been understood on the objective level. For this purpose we must detach them from the object and take them as symbolical exponents of the patient's subjective complexes. If we try to interpret the figure of Mrs. $X$ on the subjective level, we must regard it as the personification of a part-soul, or rather of a certain aspect of the dreamer. Mrs. $X$ then becomes an image of what the patient would like to be, and yet fears to be. She represents, as it were, a partial picture of the patient's future character. The fascinating artist cannot so easily be raised to the subjective level, because the unconscious artistic capacity lying dormant in the patient is already taken up by Mrs. X. It would, however, be correct to say that the artist is the image of the patient's masculinity which is not consciously realized and therefore lies in the unconscious.

[143] At this point we come back to the objective level, for without it we cannot locate the projection. The patient does not know any man who means anything special to her, apart from myself; and as her doctor I mean a good deal. Presumably therefore this content is projected on to me, though I had certainly noticed nothing of the sort. But these subtler contents never appear on the surface; they always come to light outside the consulting hour. I therefore asked her cautiously, "Tell me, how do I seem to you when you are not with me? Am I just the same?" She said, "When I am with you, you are quite pleasant, but when I am by myself, or have not seen you for some time, the picture I have of you changes in a remarkable way. Sometimes you seem quite idealized, and then again different." Here she hesitated, and I prompted her: "In what way different?" Then she said, "Sometimes you seem rather dangerous, sinister, like an evil magician or a demon. I don't know how I ever get such ideas-you are not a bit like that."

[145] It is at this point that many a treatment comes to a standstill. There is no way of getting out of the toils of the unconscious, except for the doctor to raise himself to the subjective level and to acknowledge himself as an image. But an image of what? Here lies the greatest difficulty of all. "Well now," the doctor will say, "an image of something in the unconscious of the patient." Whereupon she will say, "What, so I am a man, and a sinister, fascinating man at that, a wicked magician or demon? Not on your life! I cannot accept that, it's all nonsense. I'd sooner believe this of you!" She is right: it is preposterous to transfer such things to her. She cannot accept being turned into a demon any more than the doctor can.
1. Here Jung merely restates what we know but restates them as tautologies which use metaphors, and so this all does not explain anything.

2. This invents a new and abstract metaphorical discourse and adds nothing new of substance: "the figure of Mrs. $\mathrm{X}$ on the subjective level, we must regard it as the personification of a part-soul, or rather of a certain aspect of the dreamer. Mrs. $X$ then becomes an image of what the patient would like to be, and yet fears to be. She represents, as it were, a partial picture of the patient's future character." My italicized words show the pseudo-explanatory logic.

3. A non sequitur: "cannot so easily be raised to the subjective level, because the unconscious artistic capacity lying dormant in the patient is already taken up by Mrs. X". Why not? Can there not be two? Why and how does it get 'taken up' anyway?

4. This next bit is actually good in a roundabout way: "It would, however, be correct to say that the artist is the image of the patient's masculinity which is not consciously realized and therefore lies in the unconscious." This could properly mean that, like the artist, she wants to do all the things males are allowed to do but she is not allowed to do these or even talk them ("not consciously realized") so they do not happen for her ("lies in the unconscious"). Seeing a happy male doing all these things she wanted to, is painful but she cannot speak the source of the pain.

1. So we have got to the point that the client still wants to move forward and try new risky (male) opportunities in life but her lifelong learning of general negative consequences for women (anxiety, 'nervy') still prevents her from doing anything (depression). She cannot progress because there are hidden societal obstacles she cannot observe or name.

2. She is not projecting or transferring anything. She is getting implicit permission from Jung's therapy to do something new but still her life and relationships are so restricted that Jung is the only new person she knows who would permit this. But there are still all the anxieties and the unknown origins of these anxieties and fears which are not 'explained' by calling them archetypes arising from the unconscious.

3. Therefore, when she thinks about Jung she is thinking about exciting new possibilities (not just sexual presumably) but at the same time she still has the same old un-nameable fears from this (threats from patriarchy). 4. So it is difficult to speak about all this and hence when asked and pressed further, all the mythical, abstract and mentalistic discourses appear. Jung is like a demon because she has no concrete words for the dangers (patriarchal punishments) she senses in a risky adventure with Jung. If she had a specific example of why Jung was dangerous (someone told her some gossip) she would have said that, but because it is all hidden she once again talks in abstract responses such as demonic. And if she had had other ways to respond than just language she might have done something else, but therapy is restricted to using language on the whole as we have seen earlier. (notice how Jung later promoted drawing mandalas in therapy)

1. There can be a standstill because something big and nameless is still happening to the client and restricting her life, but we still do not know what that is (just my guesses in this column) but Jung has not even attempted to locate it in the world outside her head. Instead of looking into her world, Jung goes off into finding comparisons with abstract and mythological writings from around the world. Fascinating material, but...

2. "What, so I am a man, and a sinister, fascinating man at that, a wicked magician or demon?" No, what is meant is that she has not been allowed to have opportunities and do things which men are allowed. It is only in 'demonic' form because it is negative and hidden in real material terms. 
In her glance there lurks something of the beast of prey, something really demoniacal... Yet it is only a passing moment. The expression on the patient's face clears, and she says, as though relieved, "It is queer, but just now I had a feeling you had touched the point I could never get over in relation to my friend. It's a horrible feeling, something inhuman, evil, cruel. I simply cannot describe how queer this feeling is. It makes me hate and despise my friend when it comes, although I struggle against it with all my might."

[147] One thing is certain: if the patient gets stuck in this form of transference, the most troublesome misunderstandings lie ahead, for she will be bound to treat me as she treated her friend-in other words, the will be continually in the air giving rise to misunderstandings. It will inevitably turn out that she will see the demon in me, since she cannot accept it in herself. All insoluble conflicts come about in this fashion. And an insoluble conflict means bringing life to a standstill.

[150] These attributes always indicate that contents of the transpersonal or collective unconscious are being projected. Personal memories cannot account for "demons," or for "wicked magicians," although everyone has, of course, at one time or another heard or read of these things... But that is mythology, i.e., collective psyche, and not individual psyche. In so far as through our unconscious we have a share in the historical collective psyche, we live naturally and unconsciously in a world of werewolves, demons, magicians, etc., for these are things which all previous ages have invested with tremendous affectivity. Equally we have a share in gods and devils, saviours and criminals; but it would be absurd to attribute these potentialities of the unconscious to ourselves personally. It is therefore absolutely essential to make the sharpest possible demarcation between the personal and the impersonal attributes of the psyche.
1. She is experiencing the hidden pressures and all the negativity and faceless anxiety that induces because it is basically not fair to women: "It's a horrible feeling, something inhuman, evil, cruel". Basically this is correct in her world.

2. She recognizes (without the words) that the hidden patriarchal pressures are also mediating the problems with her friend relationship: "It makes me hate and despise my friend when it comes, although I struggle against it with all my might."

3. This recognizes that even within their personal problems there are hidden societal forces that are making it difficult for both of them to have a satisfying relationship, but it makes her blame her friend for the (patriarchal) things she cannot even name, even though she knows this is wrong.

1. She does not have an inner roadblock. She has always had a major external obstruction in her life which cannot be seen or located in a targetno particular man is doing this to her.

2. Again, there is nothing transferred or projected. This all means that if she tried to be 'gay', wild or frivolous with Jung (sadly, as the only person she could try this with), she will also end up blaming him for her woes. But just like her friend, it is not really about Jung but about her messing up relationships because she has not been allowed the opportunities she might have wanted, for no good or speakable reason-it was just forced on her from birth as a female through the already existing patriarchal structures in society. In an earlier time, she could have easily blamed it on her actual father.

1. The abstractions, metaphors and mythologizing really tell us that we are dealing with larger 'collective' forces which Jung cannot even analyse or speak about.

2. She does not start talking and dreaming about demons because of a hidden layer of inherited unconscious, but because that is a common way of trying to describe or talk when you are in a bad situation which cannot be described. The unconscious is language or discourse (Lacan).

3. "It is therefore absolutely essential to make the sharpest possible demarcation between the personal and the impersonal attributes of the psyche." This might sound good but it is not looking in the right place for interventions. This differentiates between what is conflictual in a person's life which you can see, and those things you cannot see, but in reality they are both always there. The 'collective unconscious' signs do present the therapist with indications that there are strong hidden pressures on the person. The clients' uses of language will give you clues. Similarly, outside of language, if a client is 'crying for no reason' then there is a hidden stress or conflict in their external world which they cannot observe of speak about. But you might need to get out of the office to find it.

4. Individuation is important but only if you explore that which is difficult to talk about. Try and name the external conflicts and then see how they might be changed in the client's life. Do political agitation as some feminist therapies do. Go and find

the societal structures ("impersonal attributes") pressuring her into forced choices throughout her entire life. Change those if you can.

5. But what Jung fails to understand is that the societal ('collective unconscious') is already in the personal unconscious stuff. They are not separate. The client's 'personal problems' with her friend already result from the 'collective problems' (patriarchy), since they form the very basis of the senseless and repeated fights. So, he has not really dealt properly with the 'personal' issues to begin with if he has not looked at what larger forces are in play. 


\section{Conclusions and implications for developing 'societal' therapies}

\begin{abstract}
This attitude towards the reality of the psyche contrasts strikingly with that to which Jung often refers as 'a nothing-but attitude.' Those who hold this point of view continually belittle psychic manifestations, especially experiences which cannot easily be connected with outside events, and refer to them disparagingly as 'nothing but imagination', or 'merely subjective'. Jung, on the other hand, gives the inner or psychic process a value equal to the outer or environmental one. (Fordham, 1966, p. 17, italics added)
\end{abstract}

Fordham unwittingly puts the point of this paper well: when painful life events "cannot easily be connected with outside events" then laypersons, psychiatrists and shamans alike respond with similar language strategies and discourses-abstraction, metaphors, mentalisms, personifications, etc. What Fordham fails to consider is the question: but are you looking hard enough for those outside events, with the right methods and in the right places since talking alone is no longer enough? This is where contemporary behaviour therapies are in a better position to (1) recognize the possibilities of concrete societal shaping of 'mental health' behaviours, and then (2) work with language or other means to change those environments or the client's place in those environments.

What Jung calls 'psychic' are externally determined conflictual events for his client, but neither of them can observe or know how to analyse the societal links for this. They need better training in sociology rather than mythology. We should take ids, superegos, complexes and archetypes seriously, but as important phenomena of language use and our learned discursive responses rather than as real 'inner' events. All the metaphors Jung and others have constructed around delving 'deeper' into the 'unconscious' are really about inventing metaphors for delving more thoroughly into ways to 'explain' the external, societal constraints on a person's life which cannot easily be seen.

The analysis of this paper suggests that the manner of substituting abstract discourses for the external but unobservable new pressures of modern life was dealt with in slightly different ways for Jung, Charcot, Janet and Freud, but arose from new symptoms stemming from the larger societal changes to social relationships-our families have largely been replaced by amorphous strangers for most interactions in our lives. Modern therapy also began at that same time and I have argued earlier in this paper that the limits of therapies since then were also shaped by these same changes in modern society, especially the bureaucratic practices and the reliance on language use and rules (Braedley \& Luxton, 2010; Gerth \& Mills, 1954; Giddens, 1991; Hummel, 2014; Rose, 1999; Weber, 1947).

With Jung's case-study, I have focused primarily on the hidden patriarchal contexts of modern life but I could equally have focused on other societal shapers of the client's life (Guerin, 2016a). Unfortunately, we had no information about the other societal forces on her life (such as economics) because Jung focused on her immediate social relationships and wrote about that. In that era, however, as now, economics was an important but hidden shaper of what we can and cannot do (Guerin, 2017b), and if this client had been wealthy she might have been able to do more of what she wanted and pursue her desired artistic future. On the other hand, many economic pursuits in life would still have not ever been possible for any woman.

\section{What can we learn about therapies from this?}

The implications of these arguments for therapeutic practice is that if a client is talking about their problems and issues and your conversations are abstract and mentalistic, or if a client is frequently crying or acting 'emotional' but 'without any known reason', or if a client falls into the categories of generalised depression or generalised anxiety, then there is a bigger problem which they cannot identify and which is going beyond any problems with their immediate family and friends. As a metaphor Jung said that at this stage the problem has moved from the personal unconscious to the collective unconscious, but what is really happening is that the problem is simply not one about the immediate social relationships and resource conflicts in the client's life, but about bigger societal forces and 
changes shaping the client's opportunities, barriers, hurdles, limits, or glass ceilings. This is liable to need observations outside the office and analyses in terms of the client's contexts of politics, patriarchy (both for men and women), opportunities and inequalities, decolonization, economics, bureaucratic, and cultural practices.

At this point, traditional therapists should not reach for their mythology textbooks or Sophocles' plays, but for textbooks on feminisms, economics, effects of neo-liberalism, sociology, decolonization, and politics. Where possible, they should spend time in their client's life world and, like feminist therapists and social workers, work with the client on how to resist and change these larger societal forces or else send them to someone who knows how to do this (Alinsky, 1971; Guerin, 2005, 2010; Lee, 2003; Mattaini, 2013; McFarlane \& Schabus, 2017; NiaNia, Bush \& Epston, 2016; Sharp, 1973; Wilson \& Yellow Bird, 2005).

Therapists based in a behaviour analysis background are at an advantage since they will already be looking for environmental contingencies which have shaped, and are shaping, their client's behaviours. But I am urging them to consider even further how societal structures are directly shaping human behaviours but these are not likely to be noticed. They have the training but Skinner (1953, 1957) did no research into these human behaviours, did not study what sociologists, political researchers, and social anthropologists could already tell us about these, and only wrote conceptually trying to base it all on animal models with simple reinforcement and punishment as units.

What I am saying in this paper actually comes, I believe, from the core of behaviour or functional analytic principles: (1) analyse behaviour in its context; (2) describe the contexts and consequences properly first; (3) look for the material outcomes or consequences which shape behaviour including language use; and (4) change the behaviour by changing the environment or context. But behaviour analysis has not focused enough on all the contexts of life, especially how things work in modern life now. It is as if societal, political, economic, bureaucratic, colonization, patriarchal and other contexts do not shape our behaviour, but this is understandable since they are difficult to observe and name. As stated at the beginning, this all arises when you take a broader view of how social events and their material consequences operate in life, but, I believe, this is based still on behaviour analytic principles.

So, in reality, the therapist does not have to leave the office but they should consider recommending their clients to those who know more about helping people deal with societal inequalities and barriers, how to deal with bureaucracies, and how to survive life in a generalized man's world. But as I know from social work, community-based research, social anthropology and my own participatory research, going out into the person's world and participating is the best way to observe those societal forces and even experience them yourself. When you go out into the home of the person who is struggling in your office to tell you what is wrong, you will see poverty, bullying and privileged males, little support from welfare bureaucrats, and threats of real violence. Then you will not be wanting to mythologize this or just talk about theories. You will be wanting to help them change those bad environments which have shaped their 'mental health' issues (Guerin, 2017b), and not just attempt to reshape new language strategies in the office to alleviate some of that stress (although that does help, of course).

For me this has always been the point of behaviour analytic interventions-change the behaviour by changing the environment-but we have had narrow ideas of what those 'environments' are made of. An interesting case is the inclusion of mindfulness training with many therapies now. One is presumably doing this to have the client learn to focus on, attend to, and be aware of (articulate) possibilities in their external worlds which can then be addressed. However, from what I have argued, mindfulness would be better reframed as 'contextual awareness' training and include studying sociology, decolonization, feminisms, and social anthropology to be more aware of the societal environments shaping one's behaviour, rather than just focusing on being mindful of sensations as is often done now.

Other aspects of current $3^{\text {rd }}$ Wave varieties of behaviour therapy also suggest a similar path forward. As one example, 'experiential avoidance' (e. 
g., Hayes, Strosahl \& Wilson, 1999) can be seen as one more way people behave when not knowing how to react or to talk about the pressures and stresses from lack of societal opportunities, economics, bureaucracies and other modern shapers of behaviours. It is a response of avoiding acting and talking-even avoiding those common socially acceptable 'explanations' or theories-when one knows there is a pressure but it is hidden from easy observation by client and therapist. The emotional behaviours mentioned earlier will still be present of course.

While optimistic that the most recent behavioural therapies can pick up on this and expand the environments they explore with clients, maybe in a more participatory way, one must not be too optimistic of outcomes. While finding that there are societal constraints which have shaped a client's behaviour is one thing, changing these is another. As feminist therapists have done for some time, one must perhaps work first to protect and help the client function by changing the worst of the immediate pressures on them, because changing the whole of society is obviously not going to happen easily. However, feminist therapies have found that even getting women involved in doing activist work helps them. While it may be that the pressures and constraints on people from living in our modern capitalist and neoliberal world is leading to increased anxiety and depression (Guerin, 2017b), that system will not be changed easily.

Despite this definite limit to "change the behaviour by changing the problem environment", I believe that being aware of these hidden societal and cultural shapers is beneficial for guiding clients and preventing the run-away theories and metaphors we have seen in traditional therapies like Jung's. We might not be able to change society overnight, but if we are more aware of what is really shaping the client's 'mental health' behaviours, behaviours which have been their attempt to cope with hidden societal pressures, then therapists can guide the client to achieve at least local solutions which work for them and their loved ones.

\section{References}

Alinsky, S. D. (1971). Rules for radicals: A pragmatic primer for realistic radicals. New York: Vintage.

Barnes-Holmes, D., \& Hayes, S. C. (2003). A reply to Galizio's "The abstracted operant: A review of Relational Frame Theory: A post-Skinnerian account of human language and cognition". The Behavior Analyst, 26, 305-310.

Bem, D. J. (1965). An experimental analysis of self-persuasion. Journal of Experimental Social Psychology, 1, 199-218. doi:10.1016/00221031(65)90026-0

Braedley, S., \& Luxton, M. (2010). Neoliberalism and everyday life. Montreal: McGill-Queen's University Press.

Breuer, J. and Freud, S. (1895/1974). Studies on hysteria. (Penguin Freud Library Volume 3). London: Penguin.

Costa, L., \& Fausto, C. (2010). The return of the animists: Recent studies of Amazonian ontologies. Religion and Society: Advances in Research, 1, 89-109. doi: 10.3167/arrs.2010.010107

Edwards, D. (1999). Emotion discourse. Culture \& Psychology, 5, 271-291. doi: 10.1177/1354067X9953001

Fordham, F. (1966). An introduction to Jung's psychology. London: Penguin.

Edwards, D., \& Potter, J. (1993). Language and causation: A discursive action model of description and attribution. Psychological Review, 100, 2341. doi: 10.1037/0033-295X.100.1.23

Frith, H., \& Kitzinger, C. (1998). 'Emotion work' as a participant resource: A feminist analysis of young women's talk-in-interaction. Sociology, 32, 299-320.

Fromene, R., Guerin, B., \& Krieg, A. (2014). Australian Indigenous clients with a Borderline Personality Disorder diagnosis: A contextual re- view of the literature. The Psychological Record, 64, 559-567.

Gerth, H., \& Mills, C. W. (1954). Character and social structure: The psychology of social institutions. London: Routledge \& Kegan Paul.

Giddens, A. (1991). Modernity and self-identity: Self and society in late modern age. Oxford: Polity Press. 
Graham, L. (1993). A public sphere in Amazonia? The depersonalized collaborative construction of discourse in Xavante. American Ethnologist, 20, 717-741.

Gray, F. (2008). Jung, Irigaray, individuation: Philosophy, analytical psychology, and the question of the feminine. London: Routledge.

Guerin, B. (1994). Analyzing social behavior: Behavior analysis and the social sciences. Reno, Nevada: Context Press.

Guerin, B. (2001). Individuals as social relationships: 18 ways that acting alone can be thought of as social behavior. Review of General Psychology, 5, 406-428. doi: 0.1037/10892680.5.4.406

Guerin, B. (2004). Handbook for analyzing the social strategies of everyday life. Reno, Nevada: Context Press.

Guerin, B. (2005). Handbook of interventions for changing people and communities. Reno, Nevada: Context Press.

Guerin, B. (2010). A framework for decolonization interventions: Broadening the focus for improving the health and wellbeing of Indigenous communities. Pimatisiwin: A Journal of Indigenous and Aboriginal Community Health, 8, 61-83.

Guerin, B. (2016a). How to rethink human behavior: A practical guide to social contextual analysis. London: Routledge.

Guerin, B. (2016b). How to rethink psychology: New metaphors for understanding people and their behavior. London: Routledge.

Guerin, B. (2017a). Deconstructing psychological therapies as activities in context: What are the goals and what do therapists actually do? Revista Perspectivas em Análise do Comportamento, 8, 97-119. doi: 10.18761/PAC.2016.040.

Guerin, B. (2017b). How to rethink mental illness: The human contexts behind the labels. London: Routledge.

Guerin, B. (2019). Contextualizing music to enhance music therapy. Unpublished paper. University of South Australia.

Guerin, B., \& Guerin, P. (2012). Re-thinking mental health for Indigenous Australian communities: Communities as context for mental health. Community Development Journal, 47 (4), 555570. doi:10.1093/cdj/bss030
Guerin, B., \& Ortolan, M. O. (2017). Analyzing domestic violence behaviors in their contexts: Violence as a continuation of social strategies by other means. Behavior and Social Issues, 26, 5-26.

Hayes, S. C., Strosahl, K. D., \& Wilson, K. G. (1999). Acceptance and Commitment Therapy: An experiential approach to behavior change. New York: Guilford Press.

Hochschild, A. R. (1979). Emotion work, feeling rules, and social structure. American Journal of Sociology, 85, 551-575. doi:10.1086/227049

Howard, C., Tuffin, K., \& Stephens, C. (2000). Unspeakable emotion: A discursive analysis of police talk about reactions to trauma. Journal of Language and Social Psychology, 19, 295-314. doi: 10.1177/0261927X00019003002

Hummel, R. P. (2014). The bureaucratic experience: The post-modern challenge. London: Taylor \& Francis.

Ingold, T. (2006). Rethinking the animate, reani-mating thought. Ethnos, 71, 9-20. doi: 10.1080/00141840600603111

Johnstone, L. \& Boyle, M. with Cromby, J., Dillon, J., Harper, D., Kinderman, P., Longden, E., Pilgrim, D. \& Read, J. (2018). The Power Threat Meaning Framework: Towards the identification of patterns in emotional distress, unusual experiences and troubled or troubling behaviour, as an alternative to functional psychiatric diagnosis. Leicester: British Psychological Society.

Jung, C. G. (1917). On the psychology of the unconscious. NY: Bollington Foundation.

Kulkarni, C. (1997). Lesbians and lesbianisms: A post-Jungian perspective. London: Routledge.

Lacan, J. (2006/1953). The function and field of speech and language in psychoanalysis. In Écrits: The first complete edition in English. NY: W. W. Norton.

Lee, B. (2003). The military strategy of women and children. NY: Kersplebedeb.

Lévi-Strauss, C. (1966). The savage mind. London: Weidenfeld \& Nicolson.

Mattaini, M. A. (2013). Strategic nonviolent Power: The Science of Satyagraha: Seattle: University of Washington Press.

McEnteggart, C., Barnes-Holmes, Y., Hussey, I., \& Barnes-Holmes, D. (2015). The ties be- 
tween a basic science of language and cognition and clinical applications. Current Opinion in Psychology, 2, 56-59. doi: 10.1016/j.copsyc.2014.11.017

McFarlane, P., \& Schabus, N. (2017). Whose land is it anyway? Canada: Federation of PostSecondary Educators of BC.

Mead, G. H. (1934). Mind, self, and society from the standpoint of a social behaviorist. Chicago: University of Chicago Press.

Mills, C. W. (1940). Situated actions and vocabularies of motive. American Sociological Review, 5, 904-913.

NiaNia, W., Bush, A., \& Epston, D. (2016). Collaborative and Indigenous mental health therapy: Tataihono - Stories of Maori healing and psychiatry. London: Routledge.

Nisbett, R. E., \& Wilson, T. D. (1977). Telling more than we can know: Verbal reports on mental processes. Psychological Review, 84, 231-259. doi:10.1037/0033-295X.84.3.231

Potter, J., \& Edwards, D. (1990). Nigel Lawson's tent: Discourse analysis, attribution theory and the social psychology of fact. European Journal of Social Psychology, 20, 405-424. doi: 10.1002/ ejsp.2420200504 Cite

Richards, S. (2014). “The wisdom of sociology”. Talk at TEDxLacador.

Rose, N. (1992). Engineering the human soul: Analyzing psychological expertise. Science in Context, 5, 351-369. doi: 10.1017/ S0269889700001228.

Rose, N. (1999). Governing the soul: The shaping of the private self (2nd Ed.). London: Free Association Books.

Rowland, S. (2002). Jung: A feminist revision. Cambridge, UK: Blackwell.

Ruiz, M. R. (1998). Personal agency in feminist theory: Evicting the illusive dweller. The Behavior Analyst, 21, 179-192. doi: 10.1007/BF03391962

Schwartz, A., \& Goldiamond, I. (1975). Social casework: A behavioral approach. NY: Columbia University Press.

Sharp, G. (1973). The politics of non-violent action. Boston, MA: Porter Sargent Publishers.

Skinner, B. F. (1953). Science and human behavior. New York: The Free Press.
Skinner, B. F. (1957). Verbal behavior. Englewood Cliffs: Prentice Hall.

Turner, T. (2009). The crisis in late structuralism. Perspectivism and animism: Rethinking culture, nature, spirit, and bodiliness. Tipiti, 7, 3-42.

Viveiros de Castro, E. (1992). From the enemy's point of view: Humanity and divinity in an Amazonian society. Chicago: University of Chicago Press.

Viveiros de Castro, E. (2015). The relative native: Essays on Indigenous conceptual worlds. Chicago: University of Chicago Press.

Weber, M. (1947). The theory of social and economic organization. Oxford: Oxford University Press.

Wilson, W.A. and Yellow Bird, M. (2005). For Indigenous eyes only: A decolonization handbook. Santa Fe, NM: School of American Research Press.

\section{Informações do Artigo}

Histórico do artigo:

Submetido em: 23/08/2018

Primeira decisão editorial: 10/02/2019

Versão definitiva aceita em: 14/04/2019

Editor Associado: Fernanda Castanho Calixto 